\title{
HUMOR CERITA PANJI DALAM SERAT KANDA DAN CERITA DJAJAKUSUMA
}

\author{
Pana Pramulia ${ }^{1^{*}}$ \\ ${ }^{1}$ Universitas PGRI Adi Buana Surabaya, Indonesia \\ *e-mail: panapramulia@unipasby.ac.id
}

\begin{abstract}
Abstrak
Humor tidak dapat dipisahkan dari kehidupan, karena perilaku manusia sering menimbulkan kekonyolan yang mengundang senyum dan tawa. Humor bisa sebuah persitiwa, bisa juga sikap hidup. Humor tidak hanya tumbuh dalam kehidupan nyata, tetapi tumbuh dan mengalir juga dalam cerita, imajinasi, dan sastra. Humor juga dapat ditemukan dalam Cerita Panji, terutama dalam Serat Kanda dan Cerita Djajakusuma. Artikel ini bertujuan untuk mendeskripsikan serangkaian material berupa teks humor dalam cerita Panji. Melalui uraian deskriptif diharapkan tujuan penelitian dan penafsiran data dapat tersampaikan dengan baik. Pendekatan penelitian menggunakan riset naratif, di mana cerita panji diambil dari dokumen Serat Kanda dan kisah Djajajusuma. Hasil dari penelitian ini menyajikan temuan humor dalam dialog, peristiwa dan sikap tokoh. Penyebabnya adalah kontradiksi peristiwa atau keadaan dan paradoks sikap yang diperagakan tokoh, misalnya dalam keadaan tegang (perang) menjadi satu kesatuan dengan peristiwa romantis.
\end{abstract}

Kata kunci: Humor, Panji; Serat Kanda; Cerita Djajakusuma

\begin{abstract}
Humor cannot be separated from life because human behavior often creates silliness that invites smiles and laughter. Humor can be an event. It can be an attitude to life. Humor grows in real life and grows and flows in stories, imagination, and literature. Humor can also be found in Panji Stories, especially in Serat Kanda and Stories of Djajakusuma. This article aims to describe a series of material in humorous texts in the Panji story. Through descriptive descriptions, it is hoped that the research objectives and data interpretation can be conveyed well. The research approach uses narrative research, in which the banner story is taken from the Serat Kanda document and the story of Djajajusuma. This study's results present the findings of humor in the dialogue, events, and character attitudes. The cause is a contradiction in events or circumstances, and the paradox of attitudes exhibited by the characters, for example, in a tense state (war), becomes one unit with romantic events.
\end{abstract}

Keywords: Humor, Panji; Serat Kanda; Djajakusuma Story

This is an open access article under the CC BY-SA license.

Copyright @ 2021 by Author. Published by Universitas Pendidikan Ganesha.

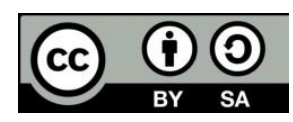




\section{PENDAHULUAN}

Seluruh peristiwa yang terjadi di dunia, pasti terdapat fenomena unik di dalamnya, salah satunya humor. Namun, tidak semua manusia dapat menangkap fenomena humor tersebut. Orang yang dapat menangkap humor berarti mempunyai banyak energi kegembiraan di dalam dirinya. Artinya, humor berkaitan erat dengan kegembiraan, kelucuan, canda tawa, dan sejenisnya. Orang yang mudah bergembira dan bahkan tertawa ketika mengalami sebuah peristiwa, walaupun menyedihkan dapat dikatakan sebagai orang yang mudah memunculkan humor. Humor bisa peristiwa, bisa juga sikap hidup. Dalam hal sikap hidup, humor merupakan hal penting bagi manusia sebagai media untuk menggembirakan hidup dan atau melupakan kesedihan.

Sedangkan sebagai sebuah peristiwa humor tidak sama dengan dagelan, lawak, dan lelucon, walaupun sama-sama dapat membuat tertawa. Dagelan, lawak, lelucon mempunyai unsur kesengajaan pelaku untuk membuat orang tertawa, tetapi humor tidak demikian. Humor muncul begitu saja di dalam sebuah peristiwa tanpa direncanakan dan diprogram sebelumnya. Walaupun demikian, humor dapat membuat orang tertawa. Humor adalah peristiwa paradoks yang ada dalam kehidupan manusia. Humor merupakan hal yang merangsang perubahan mendadak dari suatu rasa penuh harapan menjadi nihil (Suprana, 2013:8). Humor yang terjadi dalam sebuah peristiwa memuat sebuah realitas yang tidak sesuai dengan keinginan. Ketidaksesuaian antara realitas dengan keinginan akan dapat memunculkan kelucuan. Seseorang yang mudah bergembira akan mampu menangkap dan tertawa menyaksikan ketidaksesuaian tersebut.

Humor merupakan sifat dari sesuatu atau suatu situasi yang kompleks yang menimbulkan keinginan untuk tertawa (Hartanti, 2008). Humor merupakan bagian penting dalam kehidupan manusia, karena tanpa peristiwa humor hidup manusia akan mudah tertekan oleh keadaan. Humor berfungsi menggembirakan dan melembutkan hidup, serta membuat manusia lebih santai menghadapi keadaan. Humor menjadi penting, karena dapat dijadikan psikoterapi dalam kehidupan (Danandjaja, 2001:10). Menurut Flugel (1959:709) kata humor berasal dari ilmu Faal kuno mengenai empat macam cairan, yaitu kuning, hitam, merah, dan putih (Danandjaja, 2001:14; Suprana, 2013:4). Empat macam cairan tersebut menentukan tingkat temperamen manusia. Apabila cairan merah yang dominan, maka seseorang akan mudah bergembira dan dapat menangkap humor dengan mudah.

Humor adalah sesuatu yang memberikan ketidaksesuaian antara apa yang diharapkan dengan apa yang dilihat dan didengar (Suprana, 2013:8). Artinya, humor semacam kecelakaan hidup manusia yang aneh atau unik dan tidak dibuat-buat, sehingga memunculkan kelucuan dan membuat orang lain tertawa. Walaupun mempunyai unsur lucu, humor bukan lawak atau lelucon. Lawak dan lelucon bisa menjadi bengis apabila mempunyai unsur rasis guna mendapatkan tawa orang lain. Lawak dan lelucon bisa memunculkan agresi terhadap orang 
lain, tetapi humor tidak karena tidak direncanakan.

Humor dan rasa humor dapat menyelamatkan hidup manusia dari keputusasaan (Haryanto, 1987:2). Humor sebagai sikap hidup atau ideologi rasa seseorang dapat membangkitkan gairah untuk melanjutkan kehidupan. Seseorang yang miskin harta belum tentu menderita, jika di dalam hatinya penuh rasa humor. Sebaliknya, orang yang kaya harta belum tentu mudah bergembira apabila tidak mempunyai rasa humor. Bisa jadi hidupnya akan ketakutan, tegang, dan seringkali diliputi kemarahan. Artinya, jika manusia memiliki rasa humor di dalam dirinya, maka akan mudah memandang segala sesuatu menjadi menyenangkan.

Artikel ini akan menguraikan data-data humor cerita panji yang terdapat dalam Serat Kanda dan cerita Djajakusuma yang terdapat dalam buku "Tjeritera Pandji dalam Perbandingan" karya Prof. Dr. R.M.Ng. Poerbatjaraka. Berikutnya, data-data humor akan dianalisis berdasarkan konsep humor yang telah disajikan. Menurut hemat penulis, tidak hanya dua cerita panji tersebut yang memunculkan humorhumor menggelitik, tetapi karena keterbatasan waktu dan halaman, maka dua cerita sudah dapat dijadikan tolok ukur, bahwa setiap cerita panji selalu menghadirkan humor.

Dalam humor ada aspek penting yang disebut tindakan verbal dan nonverbal yang berfungsi menstimulus aktivitas kognitif dan intelektual sebagai alat persepsi dan evaluasi rangsangan untuk merespon, sehingga diperagakan melalui senyum dan tawa (Utami, 2018:220-221). Sebagai contoh: pemilik stasiun televisi A sekaligus pemimpin partai $A$, begitu juga dengan pemilik stasiun televisi B menjadi ketua umum partai B. Kedua pemilik stasiun televisi tersebut mempunyai karyawan. Bisa jadi, karyawan televisi A memilih partai $B$ dan karyawan televisi B memilih partai A. Peristiwa tersebut merupakan humor yang jarang sekali dijadikan pembahasan menarik. Contoh lainnya: sebelum helm belum ada standarisasi SNI, banyak pemotor menggunakan helm jenis shorty (helm cetok). Helm shorty merupakan jenis helm yang hanya menempel di kepala dan apabila diterpa angin kencang bisa terbang begitu saja. Orang-orang yang menyaksikan peristiwa tersebut pasti akan tertawa.

Selain dalam peristiwa, humor juga banyak berserak di dalam ceritacerita, karya sastra, dan seni pertunjukan. Dalam artikel ini akan dibahas fenomena humor yang muncul dari cerita panji. Cerita panji tersebar di seluruh wilayah negara Indonesia dan bahkan sampai ke mancanegara, seperti Malaysia, Filipina, Kamboja, dan Thailand dengan berbagai macam karakternya. Di Indonesia, cerita panji menyebar dari masa ke masa melalui budaya tutur (lisan) atau biasa disebut sebagai dongeng. Istilah Panji sendiri mempunyai banyak makna, di antaranya gelar kebangsawanan, bendera kebesaran (panji-panji), dan gelar putra mahkota kerajaan (Nurcahyo, 2017:8-9). Akan tetapi, tiga pemaknaan tersebut berbeda dengan cerita panji, karena kata Panji (sebagai sebuah nama) adalah satu hal, sedangkan Cerita Panji adalah hal lainnya (Nurcahyo, 2017:12). Dalam artikel ini yang dijadikan objek kajian 
adalah Cerita Panji, khususnya dalam Serat Kanda dan cerita Djajakusuma, karena di dalamnya terdapat humor yang unik dan sesuai dengan teori humor yang disajikan.

Serat Kanda ditulis sebelum masa kejayaan kesusastraan Solo dengan menggunakan bahasa Jawa pertengahan. Serat Kanda sudah diterjemahkan ke dalam bahasa Belanda sebelum kedatangan Raffles. Serat ini dapat dikategorikan tua, karena menarik perhatian sejak lama dan bahasa serta gayanya yang kaku, terutama pada ejaannya (Porbatjaraka, 1968:81). Serat Kanda menceritakan kisah Nabi Adam sampai kisah Jaka Tingkir, atau lebih dikenal dengan sebutan Sultan Hadiwijaya. Artinya, serat ini menceritakan perjalanan banyak tokoh dengan waktu yang panjang dengan berbagai macam peristiwa yang melingkupinya, salah satunya humor.

Cerita Djajakusuma populer di kalangan kaum wanita dalam keraton Solo, karena ada bait-bait yang seringkali dinyanyikan ibu-ibu di dalam keraton untuk anak-anaknya. Cerita Djajakusuma yang dimiliki Brandes memuat tiga jidil berukuran kwarto, masing-masing diberi nomor 301, 303, dan 272 (Porbatjaraka, 1968: 119 dan 174-175). Poerbatjaraka tidak banyak menguraikan dan membuat pernyataan mengenai cerita ini, karena naskah asli tidak ada. Hanya, menurut Poerbatjaraka cerita ini tidak begitu istimewa, disebabkan tanda lagu yang tidak cocok dengan pupuh (baca: Tjeritera Pandji dalam Perbandingan" karya Prof. Dr. R.M.Ng. Poerbatjaraka, tahun 1968, halaman 119). Meskipun demikian, peristiwa-peristiwa yang dialami tokoh dalam Cerita Djajakusuma berdasarkan terjemahan Poerbatjaraka, memunculkan beberapa humor yang layak disajikan.

Penelitian tentang humor telah banyak dilakukan dalam berbagai objek dan aspek. Penelitian humor yang dimaksud, di antaranya: 1) Dyah Puspita Rini (2009) dengan judul "Hubungan Antara Sense Humor dengan Somatisasi". Temuan penelitiannya, yaitu peningkatan sense humor dapat menghindari somatisasi; 2) Dwi Budianto (2009) yang berjudul "Penyimpangan Implikatur Percakapan dalam Humor-Humor Gus Dur". Penelitian tersebut menemukan tiga maksim, yaitu maksim kualitas, maksim kuantitas, dan maksim relevansi, serta menemukan penyimpangan maksim; 3) Sicilia Anastasya (2013) dengan judul "Teknik-Teknik Humor dalam Program Komedi di Televisi Swasta Nasional Indonesia". Penelitian tersebut mengemukakan bahwa frekuensi penggunaan teknik humor tertinggi terdapat pada language; 4) Indah Ita Utami (2018) yang berjudul "Strategi Humor dalam Acara Stand Up Comedy". Temuan penelitian, yaitu para Komika banyak memanfaatkan praanggapan, pelanggaran maksim, dan implikatur. Sedangkan penelitian ini berbeda dengan empat penelitian tersebut, baik dari segi objek maupun konsep humor yang ditawarkan. Dalam penelitian lain, humor yang ditawarkan langsung merujuk pada sebuah kelucuan yang terlihat atau dapat dikatakan tidak semu. Konsep humor dalam penelitian ini mempunyai paradigma berbeda, di mana humor dimaknai sebagai sebuah hal yang tiba-tiba dan tidak disengaja dan dalam arti lain dapat dikatakan 
sebagai kelucuan yang semu. Artinya, cerita Panji dalam Serat Kanda dan Cerita Djajakusuma memang bukan cerita lucu.

Artikel yang berjudul "Humor Cerita Panji dalam Serat Kanda dan Cerita Djajakusuma" ini diharapkan dapat memantik pembaca, khususnya penulis sendiri, agar mempunyai sikap hidup humor dan menemukan humor dalam semua aspek kehidupan. Humor merupakan salah satu hal yang penting untuk diteliti, karena mempunyai fungsi penting dalam kehidupan manusia (Danandjaja, 2001:9). Humor butuh dirawat dan dilestarikan oleh setiap masyarakat Indonesia, apalagi melihat keadaan masyarakat Indonesia yang multietnis, multigolongan, multikelas, dan banyaknya peristiwa serius yang dapat mengancam keutuhan bangsa dan negara.

\section{METODE}

Penelitian ini bersifat kualitatif
yang akan serangkaian material berupa teks humor dalam cerita Panji. Melalui uraian deskriptif diharapkan tujuan penelitian dan penafsiran data dapat tersampaikan dengan baik. Pendekatan penelitian menggunakan riset naratif, di mana cerita naratif dikumpulkan melalui dokumen (naskah). Dalam pendekatan riset naratif, sumber data dapat diperoleh dari beragam bentuk, salah satunya dokumen (Creswell, 2013:98). Sumber data penelitian, yaitu Serat Kanda dan Cerita Djajakusuma yang terdapat dalam buku "Tjeritera Pandji dalam Perbandingan" karya Prof. Dr. R.M.Ng. Poerbatjaraka. Data merujuk pada perilaku dan peristiwa humor yang diperagakan dan dialami tokoh.
Sedangkan langkah-langkah analisis data, antara lain reduksi data, penyajian data, interpretasi, dan kesimpulan.

Pertama yang dilakukan mereduksi data atau melakukan proses pemilihan dan penyederhaan berdasarkan data yang telah ditandai dalam dokumen. Kedua mengorganisasi dan menyusun data sesuai dengan pola hubungan dengan konsep humor. Ketiga susunan data dianalisis berdasarkan konsep humor yang disajikan dalam artikel ini. Keempat melakukan pencarian arti atau makna dan pola-pola dari hasil penafsiran.

\section{HASIL DAN PEMBAHASAN Humor dalam Serat Kanda}

Pembahasan pertama artikel ini akan menyajikan humor-humor yang terdapat dalam Serat Kanda, khususnya Serat Kanda yang diterjemahkan Prof. Dr. R.M.Ng. Poerbatjaraka dan diterbitkan oleh Gunung Agung pada tahun 1968. Walaupun sudah diterjemahkan karakter Serat Kanda tidak diubah, artinya masih diuraikan melalui pupuh-pupuh. Humor yang disajikan berbentuk dialog maupun narasi, dan akan dianalisis menggunakan konsep humor yang telah dijelaskan sebelumnya. Data yang akan disajikan dikutip begitu saja tanpa mengubah diksi maupun ejaan bahasanya. Tujuannya untuk menjaga esensi dan otentisitas data.

"Djika demikian aku
hendak mengambilnja
sebagai mantu, jaitu
apabila anak yang kini
masih dalam kandungan
isteriku, ternjata seorang


perempuan."

(Poerbatjaraka, 1968:95).

Kutipan di atas menggambarkan kekonyolan, karena bayi yang belum lahir dan belum dapat diprediksi jenis kelaminnya, sudah didaulat untuk dijodohkan. Kutipan yang telah disajikan tersebut sejalan dengan pendapat Theodor Lipps, yaitu humor is descending incongruity (Suprana, 2013:8). Artinya, humor merupakan keganjilan, baik perilaku maupun pernyataan dari seseorang. Konsep pembaca sekarang (untuk membaca kutipan di atas) akan melihat keganjilan pada perilaku tokoh masa lalu. Keganjilan tersebut dapat menyebabkan senyum bahkan tawa bagi pembaca.

Berikut ini akan disajikan kutipan yang memang mempunyai kesan humor, walaupun sebenarnya penulis tidak dapat menemukan rasa humor di dalamnya. Apabila kutipan yang disajikan ditransformasikan dalam seni pertunjukan, bisa jadi humor akan terlihat dan dapat dipahami.

"Sadulumur berkata: Si Dojok senanti telalu banjak untung. Dapet bini putri terlalu baik, anaknja sang katong, kalok pagi duduk kursine, ngadep medja makan roti beskuwit, marteganja putih, minum kopi dan susu. Orang jang mendengarnja tertawa". (Poerbatjaraka, 1968:97).

Kutipan di atas disajikan sebagai data, karena diakhiri dengan pernyataan "Orang jang mendengarnja tertawa".
Mungkin, penulis cerita tidak menggambarkan kelucuan pada pernyataan Sadulumur, melainkan digambarkan pada sikap atau tindakan untuk menyertai pernyataannya. Apa yang dikatakan Sadulumur tersebut memunculkan kelucuan dan membuat orang lain tertawa. Seperti yang telah disajikan sebelumnya, bahwa humor sebagai sikap hidup atau ideologi rasa seseorang dapat membangkitkan gairah untuk melanjutkan kehidupan. Humor berikutnya merupakan dialog antara Raja Kadiri dengan Prasanta mengenai keadaan Panji.

"Sang Radja, yang
mendengar kedjadian itu,
pun datang ketempat
kediaman Pandji, bersama
kakaknja, Kili Sutji. Ia
menanjakan keadaan
putranja; Prasanta
mendjawab: Ah, biasa
sadja, memang kalau dia
sedih, dia djatuh pingsan".
(Poerbatjaraka, 1968:102).

Pernyataan atau jawaban Prasanta pada kutipan data di atas bukan lelucon, tetapi dapat membuat tertawa pembacanya. Konteks humor terdapat pada keseriusan dan kekhawatiran raja mengenai keadaan Panji, tetapi Prasanta bersikap dan menjawab biasa saja. "Kedjadian" yang dimaksud dalam kutipan di atas, yaitu hilangnya putri Kadiri dari keputren (diculik seorang Brahmana sakti), sehingga Panji melakukan pencarian. Peristiwa tersebut merupakan kejadian serius (sampai Panji pingsan), sehingga Raja mengkhawatirkan keadaan Panji, tetapi Prasanta menjawab "Ah, biasa 
sadja". Peristiwa serius, pingsan, disertai kekhawatiran orang lain terhadap lain orang hanya mendapatkan tanggapan santai atau biasa saja, dan inilah yang disebut humor. Hal ini merupakan paradoks kehidupan yang dapat memunculkan tawa.

"Sekarang Pandji
menampakkan r diri,
terdjadi pertengkaran
mulut, setelah itu
perkelahian, sebentar
diudara, sebentar
diangkasa, sebentar
dibumi. Achirnya sang
Brahmana melarikan diri
diangkasa. Prasanta harus
memutarnya supaja
kembali". (Poerbatjaraka,
1968:102).

Narasi di atas menggambarkan suasana perkelahian yang seru, sekaligus penuh humor jika ditransformasi dalam seni pertunjukan. Perkelahian yang berpindah-pindah tempat dan usaha Prasanta memutar sang Brahmana agar kembali berhadapan dengannya, merupakan adegan yang menegangkan juga sekaligus adegan yang dapat membuat tertawa. Apabila narasi di atas tidak dibaca dengan cermat, maka hanya akan menimbulkan kesan tegang, bahkan biasa-biasa saja. Tokoh Sadulumur (lanjutan dari narasi di atas) yang menyaksikan usaha Prasanta untuk menarik Brahmana tidak digambarkan tegang, melainkan tertawa. "Sadulumur berlutju lutju berkenaan dengan pemutaran djentera pemintal..." (Poerbatjaraka, 1968:102). Peristiwa tersebut juga dapat dikaitkan dengan konsep humor, di mana humor semacam kecelakaan hidup manusia yang aneh atau unik dan tidak dibuatbuat, sehingga memunculkan kelucuan dan membuat orang lain tertawa.

"Bekang Merdeja melihat
kedjadian itu, berpakaian
sebagai laki-laki; ia pergi
kemedan pertempuran
dan menantang musuh.
Pandji madju menemuinja.
Setelah bertengkar mulut,
Pandji menjuruhnja
menjerahkan diri; ia
hendak memperistrinja".
(Poerbatjaraka, 1968:104).

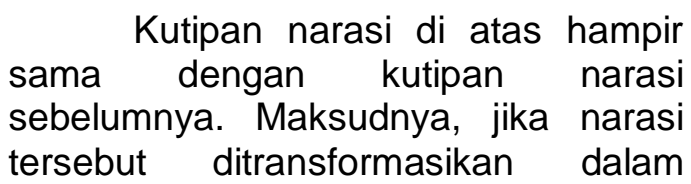
bentuk seni pertunjukan, misalnya ketoprak akan dapat membuat penonton tertawa. Bagi pembaca yang cermat akan mudah menemukan humor di dalam narasi tersebut. Alasannya, bagaimana bisa dalam keadaan perang atau bermusuhan, seseorang malah meminta musuh untuk menjadi istrinya. Dalam peristiwa tersebut antara ketegangan dan romantis bercampur menjadi satu, dan itulah humor. Artinya, jika manusia memiliki rasa humor di dalam dirinya, maka akan mudah memandang segala sesuatu menjadi menyenangkan

\section{Humor dalam Cerita Djajakusuma}

Pada pembahasan kedua akan disajikan empat data dan analisis humor yang terdapat dalam Cerita Djajakusuma, khususnya yang telah diterjemahkan Prof. Dr. R.M.Ng. 
Poerbatjaraka dalam buku "Tjeritera Pandji dalam Perbandingan" yang diterbitkan oleh Gunung Agung pada tahun 1968. Kutipan data tidak ada perbedaan dengan kutipan pada Serat Kanda. Maksudnya, data yang akan disajikan dikutip begitu saja tanpa mengubah diksi maupun ejaan bahasanya. Kutipan data yang disajikan berbentuk dialog dan narasi, kemudian dianalisis menggunakan konsep humor. Berikut uraiannya.

“...mereka mendapati
sebuah batu jang besar;
dari situlah keluar tjahaja.
Setelah batu itu dibelah
dua, keluarlah seekor
katak (dingdang), jang
mengatakan bahwa ia
sedang bertapa, karena
ingin menjadi radja Djawa.
Djati pitutur mengata-
ngatai binatang itu, katanja
ia gila dan dimintanja
pangeran merobek mulut
binatang jang kurang adjar
itu”. (Poerbatjaraka,
1968:).

Kutipan di atas menggambarkan sebuah peristiwa yang menegangkan, tetapi memunculkan kelucuan. Pembaca yang mempunyai sudut pandang humor akan membayangkan ekspresi wajah yang terkejut dari pembelah batu serta orang-orang di sekitarnya. Dapat dibayangkan, ekspresi ketegangan sebelum membelah batu, kemudian ekspresi kegembiraan setelah batu pecah menjadi dua, dan ekspresi terkejut ketika muncul seekor katak dari batu tersebut. Kronologi ekspresi yang berbeda dan berubah tersebut antara satu dengan lainnya kontradiktif, dan itulah humor. Bahkan, humor juga dapat dibaca dari pernyataan katak yang mengejutkan.

"Sang puteri
mengemukakan satu
pertanjaan lagi: Mengapa
kau pulang tidak berbadju
pada hari Djum'at?"
Suaminja mendjawab: Aku
berdjudi dikampung Tjina
dan kehabisan segala".
(Poerbatjaraka, 1968:145).

Humor dalam kutipan di atas terdapat pada jawaban suami (Miruda) yang terkesan biasa saja tanpa menunjukkan rasa salah dan penyesalan. Padahal, jika membaca dengan cermat pertanyaan Sang puteri (istri), pembaca akan menemukan ekspresi serius, marah, dan jengkel. Selain itu, humor juga dapat ditemukan dari kata "berdjudi" yang mengakibatkan "kehabisan segala" sampai kehilangan pakaian. Artinya, harta terakhir yang dijadikan bahan taruhan adalah pakaian, dan hal itu dapat dikatakan konyol, lucu, dan penuh humor. akan tetapi, humor sebenarnya terdapat pada kutipan di bawah ini karena sebenarnya Miruda berbohong mengenai jawabannya.

"Sekonjong-konjong datang
seorang perempuan dari
keraton, diutus oleh puteri
Urawan, untuk
mengembalikan pakaian
Astra Miruda jang
ketinggalan karena terburu-

Jurnal IImu Sosial dan Humaniora | 8 
buru...." (Poerbatjaraka,
1968:145).

Pembaca pasti akan menemukan humor dalam kutipan di atas, karena berkorelasi dengan kutipan sebelumnya. Pembaca akan tertawa membayangkan ekspresi malu dan ketakutan Miruda terhadap isterinya setelah terbongkar kebohongannya. Kebohongan yang terbongkar memang menyakitkan, tetapi jika dilihat dari sudut pandang humor dapat menggelikan. Kebohongan yang pada akhirnya dikonsumsi oleh publik memunculkan gelak tawa secara kolektif. Berikutnya akan disajikan kutipan pepatah yang dinyatakan Sureng-rana kepada suaminja, yaitu Djajakusuma.

"medjek tahi neng batok; biasanja: ngublak". (Poerbatjaraka, 1968:146).

Pepatah di atas apabila dilanjutkan, yaitu "ngublak tahi neng batok, muncrat ning raine dhewe". Pepatah Jawa tersebut hampir mirip maknanya dengan pepatah Melayu, yaitu "menepuk air di dulang terpercik muka sendiri". Makna dari dua pepatah itu adalah berbuat sesuatu yang merugikan diri sendiri atau melakukan perbuatan yang memalukan diri sendiri. Menurut subjektivitas peneliti, pepatah tersebut mengandung humor walaupun memuat nasihat yang serius. Isi dari pepatah tersebut bisa dianalogikan seperti seseorang yang melempar batu, tetapi batu yang dilempar mengenai dirinya sendiri atau orang meludah ke atas, tetapi ludahnya mengenai dirinya sendiri. Dalam persitiwa sehari-hari, banyak ditemukan perkataan atau pernyataan orang (buruk) yang akhirnya menimpa dirinya sendiri. Peristiwa yang demikian dapat dikatakan sebagai humor, karena orang lain yang melihat pasti tertawa.

Demikian humor yang dapat disajikan dalam artikel ini. Sebenarnya masih banyak humor yang masih berserak di dalam Serat Kanda dan cerita Djajakusuma, tetapi karena keterbatasan waktu dan halaman, penulis hanya menyajikan sembilan data (5 dari Serat Kanda dan 4 dari cerita Djajakusuma). Penulis mempunyai keyakinan, bahwa dalam cerita Panji yang lain juga banyak menyajikan humor dan kelucuan, baik peristiwa maupun perilaku tokohnya. Oleh sebab itu, cerita Panji layak untuk dianalisis melalui sudut pandang humor, karena kajian humor dalam budaya Panji maupun bidang ilmu humaniora masih belum banyak dilakukan.

\section{SIMPULAN DAN SARAN}

Artikel ini membahas dan menguraikan humor yang terdapat dalam Serat Kanda dan cerita Djajakusuma. Dua cerita tersebut merupakan hasil terjemahan Prof. Dr. R.M.Ng. Poerbatjaraka dan diterbitkan oleh Gunung Agung pada tahun 1968 dan diberi judul "Tjeritera Pandji dalam Perbandingan". Data yang diuraikan dalam artikel ini dikutip berdasarkan teks aslinya. Tujuannya untuk menjaga esensi dan otentisitas data. Berdasarkan pembahasan yang telah disajikan, humor ditemukan dalam dialog maupun peristiwa dan sikap tokoh. Humor tersaji salah satu penyebabnya adalah kontadiksi peristiwa atau keadaan dan paradoks sikap yang diperagakan tokoh, misalnya 
dalam keadaan tegang (perang) menjadi satu kesatuan dengan peristiwa romantis (menawari musuh menjadi istri). Pembaca akan tertawa membaca dua karakter peristiwa berbeda dalam ruang dan waktu yang sama, serta diperagakan tokoh yang sama pula. Selain itu, humor juga tersaji pada pepatah yang jika dimaknai dan dibayangkan menjadi sebuah kelucuan, misalnya ngublak tahi neng batok, muncrat ning raine dhewe". Artinya, humor dapat muncul kapan saja dalam sebuah peristiwa, perilaku, pernyataan, dan sebagainya. Maka, humor harus dirawat karena dapat melembutkan hidup dan dapat melupakan kesedihan.

\section{DAFTAR PUSTAKA}

Anastasya, S. (2013). Teknik-Teknik Humor dalam Program Komedi di Televisi Swasta Nasional Indonesia. Jurnal EKomunikasi Universitas Kristen Petra, 1(1), 1-11. http://publication.petra.ac.id/in dex.php/ilmukomunikasi/article/view/88

Budiyanto, D. (2009). Penyimpangan Implikatur Percakapan dalam Humor-Humor Gus Dur. Litera: Jurnal Pendidikan Bahasa, Sastra, dan Pengajarannya, 8(2), 105-117. https://journal.uny.ac.id/index. php/litera/article/view/1206/10 $\underline{16}$

Creswell, J. W. (2013). Penelitian Kualitatif dan Desain Riset. Yogyakarta: Pustaka Pelajar.

Danandjaja, J. (2001). Humor Mahasiswa. Cetakan kesepuluh. Cetakan pertama tahun 1990. Jakarta: Pustaka Sinar Harapan.

Hartanti. (2008). Apakah Selera Humor Menurunkan Stres? Sebuah Meta-analisis. Anima, Indonesian Psychological Journal, 24(1), 38-55.

Haryanto, B. (1987). Bom Tawa dari Rusia. Jakarta: Upaya Swadaya Aksara.

Nurcahyo, H. (2017). Memahami Budaya Panji. Cetakan ketiga. Sidoarjo: Pusat Konservasi Budaya Panji.

Poerbatjaraka, R. M. N. (1968). Tjeritera Pandji dalam Perbandingan. Jakarta: Gunung Agung.

Rini, D. P. (2009). Hubungan Antara Sense Humor dengan Somatisasi. Tesis. Surakarta: Universitas Muhammadiyah Surakarta. http://eprints.ums.ac.id/4839/1 /F100050028.PDF

Suprana, J. (2013). Humorologi. Jakarta: PT Elex Media Komputindo.

Utami, I. I. (2018). Strategi Humor Pada Acara Stand Up Comedy. Adabiyyat: Jurnal Bahasa dan Sastra, 2(2), 219-245. http://ejournal.uinsuka.ac.id/adab/Adabiyyat/arti cle/view/1395/836 